\title{
Prevalence and Mean Intensity of Myxobolus spp. Parasitizing Oreochromis niloticus in Cameroon
}

\author{
Guy Benoît LEKEUFACK FOLEFACK ${ }^{1}$, Chanceline MALA KENGNE ${ }^{1}$, Bienvenu FEUDJIO DONGMO ${ }^{1}$ \& \\ Abraham FOMENA ${ }^{1}$ \\ 1. University of Yaounde I, Faculty of Science, Laboratory of Parasitology and Ecology, PO. Box: 812 Yaounde, \\ Cameroon \\ Correspondence: Guy Benoît LEKEUFACK FOLEFACK, University of Yaounde I, Faculty of Science, \\ Laboratory of Parasitology and Ecology, PO. Box: 812 Yaounde, Cameroon. E-mail: leguyzo@yahoo.fr
}

Received: January 25, 2019

Accepted: February 9, 2019

Online Published: March 4, 2019

doi:10.5539/ijb.v11n2p35

URL: https://doi.org/10.5539/ijb.v11n2p35

\begin{abstract}
Oreochromis niloticus, being one of the most commonly cultured fish on earth constitutes a favorable biotope for myxosporidia. This study provides information concerning the prevalence and mean intensity of Myxobolus species recorded in the kidney and spleen of $O$. niloticus. O. niloticus were sampled in farming ponds at Bamendou in Cameroon. Classic methods concerning fishing, fish autopsy and search of Myxosporidia were used. Prevalence and mean intensity was calculated. Data analysis based on the chi-square test, Kruskal-Wallis $\mathrm{H}$ test and Mann-Whitney U test was done. The study revealed the presence of six Myxobolus species in the kidney and spleen of $O$. niloticus. All parasites species appeared frequent while their mean intensity was low or very low. The occurrence of M. foto $i$ was statistically lower $(\mathrm{P}<0.05)$ in the kidney's anterior portion while the mean intensity of $M$. agolus was statistically $(\mathrm{P}<0.01)$ higher in the anterior portion of the spleen. Myxobolus cichlidarum was not found in kidney of young fish and occurrence of M. agolus statistically increases $(\mathrm{P}<0.05)$ with host age. Host sex has significant influence $(\mathrm{P}<0.05)$ on: occurrence of M. agolus, M. fotoi, M. agolus, M. brachysporus and $M$. heterosporus; and mean intensity of $M$. fotoi. The study revealed that in $O$. niloticus, the kidney and spleen harboured the same parasites species and there were only few variations in occurrences and mean intensities of parasites species recorded as function of host organs, age and sex.
\end{abstract}

Keywords: Myxobolus spp., Oreochromis niloticus, Prevalence, mean intensity, fish parasite, Cameroon

\section{Introduction}

Oreochromis niloticus Linnnaeus, 1758, is a freshwater Cichlid and one of the world's most important food fishes. Owing to its hardy nature, and its wide range of trophic and ecological adaptations, it has been widely introduced for aquaculture, augmentation of capture fisheries and sport fishing (Trewavas, 1983; Welcomme, 1988), and is now found in virtually every country within the tropics. O. niloticus is justifiably regarded as good fish species adapted for aquaculture mainly due to its relative ease of cultivation and propagation, rapid growth and acceptability by consumers.

Despite its economic and food importance, $O$. niloticus constitute a favorable biotope for the development of a large number of parasites among which myxosporidia (Fomena, Marques \& Bouix, 1993; Fonkwa, Lekeufack, Tchuinkam , Ishtiyaq \& Tchoumboue, 2018; Landsberg, 1985). Myxosporidia are parasites characterized by extensive morphological simplification and complex life cycles exploiting invertebrate and vertebrate (primarily fish) hosts in freshwater and marine environments (Lom \& Dyková, 2006). Currently, there are some 2300 nominal species of myxozoans classified into 64 genera and 17 families (Fiala, Bartosova-Sojkova \& Whipps, 2015). Both coelozoic and histozoic myxosporidia stages are responsible of noticeable pathology and frequently cause fish death (Lom \& Dyková, 2006). With more than 905 described species, the genus Myxobolus Bütschli, 1882 has the highest number of Myxosporidia species and the lagest global distribution (Eiras, Molnár and Lu, 2005; Eiras, Zhang and Molnar, 2014). Out of known Myxobolus species, 185 (20.44\%) and 56 (6.18\%) species have been recorded respectively in the kidney and spleen of infected fish. In fish, kidney and spleen are the common sites of establishment for various Myxobolus species.

Since teleost fish have no medullary cavity in their bones, the spleen and kidney serve as the primary haematopoietic organs (Agius \& Roberts, 2003). Furthermore, as fish have no lymph nodes, the spleen alone 
plays an essential role in antigen trapping (Press, 1998) while the kidney, receiving the vast majority of postbranchial blood is expected to receive all pathogens present in the blood. Accounts on fish host and organ specificity of myxosporidia species are often confusing (Molnár, 2002, 2007), including those concerning species of the genus Myxobolus. Whereas sporogenesis of some coelozoic species was originally described in the kidney, other authors observed that spores of some histozoic species, secondarily occur in haematopoietic organs (Molnár, 2007). According to Dyková (1984), myxospores are generally transported by macrophages homing on macrophage centers of haematopoietic organs, where they are destroyed.

In the present study, we contributed to increase fish production potential through a better knowledge of their pathologies by providing comprehensive information concerning the prevalence and mean intensity of different Myxobolus species recorded in the kidney and spleen of O. niloticus, as function of host organs, age and sex.

\section{Material and Methods}

\subsection{Data on Host Fish and Study Site}

Oreochromis niloticus Linnaeus, 1758 (Cichlidae) is widely distributed around the world. Forty six specimens of $O$. niloticus with standard length varying between 40 and $102 \mathrm{~mm}$ were harvested within rainy season in fish farming ponds at Bamendou, a small village in the Menoua Division, West Region of Cameroon. This village is elevated 1400 to $1900 \mathrm{~m}$, between $5^{\circ} 22^{\prime} 30^{\prime \prime}$ and $5^{\circ} 28^{\prime}$ North latitude and $10^{\circ} 7^{\prime} 30$ and $10^{\circ} 15^{\prime}$ longitude East. The climate is tropical type in this locality which is characterized by one rainy season (mid-March to mid-November) and one dry season (mid-November to mid-March). Annually, the study site experience heavy rainfall (1500 $2000 \mathrm{~mm})$, average temperature is low $\left(19-20^{\circ} \mathrm{C}\right)$ and night temperatures can reach $5^{\circ} \mathrm{C}$.

\subsection{Fishing and Fish Conservation}

Fish capture was carried out using a $1 \mathrm{~cm}^{2}$ mesh gill net. In the field, once the fish were caught, a buttonhole was made on the abdominal region of each fish individual. The latter were immediately immersed in a $10 \%$ formalin solution contained in a plastic container. Identification of the fish specimens was done using the key provided by Stiassny, Teugels and Hopkins (2007).

\subsection{Dissection of Fish and Parasites Identification}

In the laboratory, the standard length of each fish individual was measured to the nearest millimeter. Using the modified Yule formula, fish individuals were grouped into three size classes. Fish sex was determined after identification of the gonads. Each fish specimen was dissected for the extraction of the kidney and spleen. The length of the kidney and spleen of each $O$. niloticus individual was measured to the nearest millimeter and each of these organs was divided into three equal portions (anterior, medial and posterior). Each organ portion was isolated in a petri dish containing distilled water in order to avoid contamination of one portion by the others. Smears of each portion of the kidney and spleen were mounted between slide and cover slide and examined at the 40X objective of the microscope. Myxospores were identified with the 100X objective of an YVYMEN optical microscope taken into account the variables proposed by Lom and Arthur (1989). Microphotography of myxospores was performed using an Olympus BH-2 microscope equipped with a microphotograph device. For a quantitative estimation of myxospores in the organs, three smears were made per organ portion and spore counting was done in 40 fields of each smear at $40 \mathrm{X}$ objective.

\subsection{Parasites status and data analysis}

According to Bush, Lafferty, Lotz and Shostak (1997), the infection rate was estimated as the number of $O$. niloticus individuals infected with one or more individuals of a particular Myxosporidia species divided by the total number of $O$. niloticus examined. Also referring to Bush et al. (1997), the mean intensity was calculated as the average number of spores of a particular species of Myxosporidia among the infected members of $O$. niloticus found in the sample divided by the number of $O$. niloticus infected with that Myxosporidia species.

Analysis of the status of each Myxosporidia species was made according to Valtomen, Holmes and Koskivaara (1997). Thus, the species are qualified as frequent (or common or principal) if Prevalence ( $\mathrm{Pr})>50 \%$, Less frequent (or secondary or intermediate) if $10 \% \leq \operatorname{Pr} \leq 50 \%$, and scarce (or satellite) if $\operatorname{Pr}<10 \%$. Following Bilong Bilong \& Njiné (1998), the mean intensity (I) was judged very weak if I $<10$, weak if $10 \leq \mathrm{I}<50$, average if $50 \leq \mathrm{I} \leq 100$ and very high if $\mathrm{I}>100$.

Using the statistical package SPSS version 16.0, the data analysis was based on: (1) the chi-square test $\left(\chi^{2}\right)$ for the comparison of the infection rates of Myxosporidia species; (2) the Kruskal-Wallis $\mathrm{H}$ test for the comparison of the mean intensity of Myxosporidia species; (3) The Mann-Whitney U test for the comparison of the paired mean 
intensity of Myxosporidia species. All statistical tests were considered significant when the significance level (P) was less than $0.05(\mathrm{P}<0.05)$.

\section{Results}

\subsection{Population structure of Oreochromis niloticus}

The standard length (SL) of $O$. niloticus sampled ranged from 40 to $102 \mathrm{~mm}$, with an average of $76.37 \pm 12.2 \mathrm{~mm}$. Based on these lengths, three size classes of $27 \mathrm{~mm}$ amplitude were obtained. The sex ratio was biased toward females and is worth $42.86 \%$.

Specimens of $O$. niloticus examined harboured six species of myxosporidia in both the kidney and spleen, all belonging to the genus Myxobolus Bütschli 1882 (Figure 1). Only polyspecific infections were observed and the number of parasites species carried by each host individual ranged from 2 to 6 .
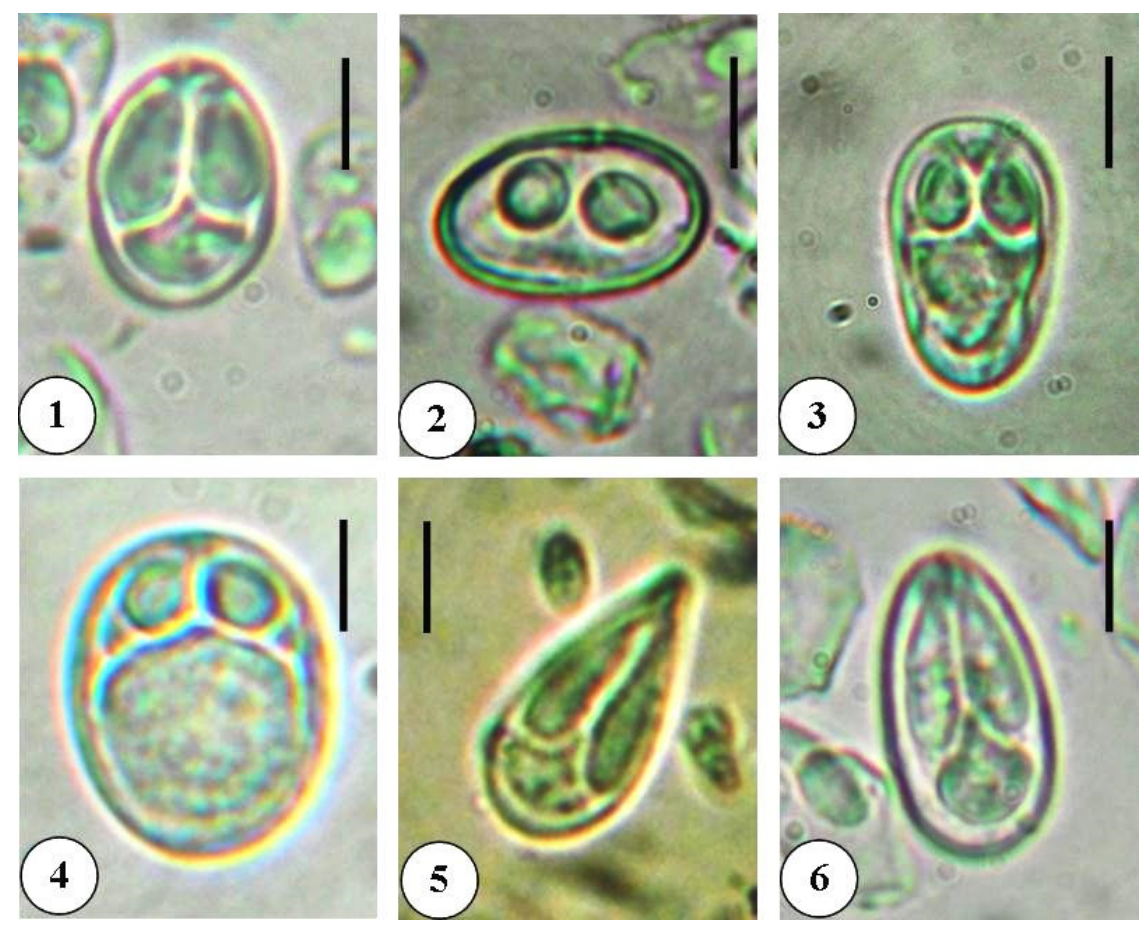

Figure 1. Microphotographs (optical microscopy) of fresh spores of: (1) Myxobolus agolus; (2) Myxobolus brachysporus; (3) Myxobolus cichlidarum; (4) Myxobolus fotoi; (5) M. heterosporus; (6) Myxobolus israelensis. Scale bar: $5 \mu \mathrm{m}$.

\subsection{Prevalence and status of parasites species recorded}

Specimens of $O$. niloticus examined harboured in the kidney and spleen, six myxosporidia species belonging to the genus Myxobolus. These parasite species were: Myxobolus agolus Landsberg, 1985; M. brachysporus Baker, 1963; M. cichlidarum Abakar-Ousman, Fomena, Ngassam and Bouix, 2006; M. fotoi Fomena, Marques and Bouix, 1993; M. heterosporus Baker, 1963 and Myxobolus israelensis Landsberg, 1985. In the population of $O$. niloticus sampled, parasites prevalence ranged from 56.5 (M. cichlidarum) to $91.3 \%$ (M. brachysporus) (Table 1). All parasites species appeared frequent (prevalence $>50 \%$ ). In the kidney and spleen, parasite infection rates ranged from 28.3 (M. cichlidarum) to $89.1 \%$ (M. agolus) and 47.8 (M. cichlidarum) to $84.8 \%$ (M. brachysporus) respectively (Table 1). Variation between infection rates is highly significant $(\mathrm{P}<0.01)$ in the kidney and spleen. A similar result was obtained after combining infections of kidney and spleen (kidney + spleen) (Table 1). Comparing parasite species two by two, there are significant differences $(\mathrm{P}<0.05)$ in the variation of infection rates of certain parasite species. Thus, except $M$. heterosporus, the prevalence of $M$. cichlidarum is statistically $(\mathrm{P}<0.05)$ lower than that of other parasite species. In addition, the prevalence of $M$. heterosporus is statistically $(\mathrm{P}<0.05)$ lower than that of M. agolus and M. brachysporus. In the kidney, the infection rate of M. ciclidarum is statistically $(\mathrm{P}<0.05)$ lower than that of all other parasite species. Moreover, the occurrence of $M$. agolus is statistically higher $(\mathrm{P}<0.05)$ than those of $M$. fotoi and M. heterosporus. In the spleen, the percentage of 
infection of $M$. brachysporus is statistically higher $(\mathrm{P}<0.05)$ than those of $M$. cichlidarum, M. fotoi and $M$. heterosporus. Furthermore, the proportion of spleen parasitized by $M$. cichlidarum is statistically low $(\mathrm{P}<0.05)$ compared to the proportion of spleen parasitized by M. agolus and M. israelensis. Except M. agolus, with an occurrence significantly high $(\mathrm{P}<0.05)$ in the kidney, species of Myxosporidia harvested equally $(\mathrm{P}>0.05)$ parasitized the kidney and spleen of examined fish.

Table 1. Infection rates and mean intensities of Myxosporidia parasites of Oreochromis niloticus

\begin{tabular}{|c|c|c|c|c|c|}
\hline Parasite species & $\begin{array}{l}\text { Epidemiological } \\
\text { index }\end{array}$ & Kidney & Spleen & Kidney + Spleen & $\begin{array}{l}\text { Value of the statistical } \\
\text { test (kidney vs spleen) }\end{array}$ \\
\hline \multirow[t]{3}{*}{ M. agolus } & $\mathrm{n}$ & 41 & 33 & 42 & \\
\hline & $\operatorname{Pr}(\%)$ & 89.1 & 71.7 & 91.3 & $\chi^{2}=4.420 *$ \\
\hline & $\mathrm{I}(\mathrm{Vmin}-\mathrm{Vmax}) \delta$ & $7.9(2-55) 8.9$ & $9.2(2-21) 5.5$ & $14.9(2-64) 12.1$ & $\mathrm{U}=\mathbf{5 1 8 . 5}$ \\
\hline \multirow[t]{3}{*}{ M. brachysporus } & $\mathrm{n}$ & 39 & 39 & 43 & \\
\hline & $\operatorname{Pr}(\%)$ & 84.8 & 84.8 & 93.5 & $\chi^{2}=\mathbf{0}$ \\
\hline & $\mathrm{I}(\mathrm{Vmin}-\mathrm{Vmax}) \delta$ & $11.2(1-41) 11$ & $12.6(1-67) 12.6$ & $21.6(2-106) 22$ & $\mathrm{U}=695$ \\
\hline \multirow[t]{3}{*}{ M. cichlidarum } & $\mathrm{n}$ & 13 & 22 & 26 & \\
\hline & $\operatorname{Pr}(\%)$ & 28.3 & 47.8 & 56.5 & $\chi^{2}=3.735$ \\
\hline & $\mathrm{I}(\mathrm{Vmin}-\mathrm{Vmax}) \delta$ & $2(1-5) 1.2$ & $2.1(1-7) 1.4$ & $2.8(1-12) 2.3$ & $\mathrm{U}=141.5$ \\
\hline \multirow[t]{3}{*}{ M. fotoi } & $\mathrm{n}$ & 32 & 30 & 39 & \\
\hline & $\operatorname{Pr}(\%)$ & 69.6 & 65.2 & 84.8 & $\chi^{2}=0.198$ \\
\hline & $\mathrm{I}(\mathrm{Vmin}-\mathrm{Vmax}) \delta$ & $5.7(1-22) 4.9$ & $5.5(1-22) 4.3$ & $8.9(1-44) 8.5$ & $\mathrm{U}=471$ \\
\hline \multirow[t]{3}{*}{ M. heterosporus } & $\mathrm{n}$ & 31 & 29 & 33 & \\
\hline & $\operatorname{Pr}(\%)$ & 67.4 & 63 & 71.7 & $\chi^{2}=0.192$ \\
\hline & $\mathrm{I}(\mathrm{V} \min -\mathrm{V} \max ) \delta$ & $8.9(1-41) 9.6$ & $10.1(1-38) 9.7$ & $18.1(1-66) 17.3$ & $\mathrm{U}=414.5$ \\
\hline \multirow[t]{3}{*}{ M. israelensis } & $\mathrm{n}$ & 37 & 32 & 37 & \\
\hline & $\operatorname{Pr}(\%)$ & 80.4 & 69.6 & 80.4 & $\chi^{2}=1.449$ \\
\hline & $\mathrm{I}(\mathrm{V} \min -\mathrm{Vmax}) \delta$ & $10(1-41) 9.2$ & $11.3(1-91) 16.2$ & $19.7(2-114) 21.4$ & $\mathrm{U}=\mathbf{5 8 6 . 5}$ \\
\hline Value of the & & $\chi^{2}=53.43 * *$ & $\chi^{2}=15.23 * *$ & $\chi^{2}=27.06 * *$ & \\
\hline statistical test & & $\mathbf{H}=29.1 * *$ & $H=40.19^{* *}$ & $H=56.62 * *$ & \\
\hline
\end{tabular}

M.: Myxobolus; n: number of parasitized fish; Pr: infection rate; I: mean intensity; Vmin: minimum value; Vmax maximum value; $\chi^{2}$ : chi-squared test value; H: Kruskal-Wallis test value; U: Mann-Whitney test value; \%: percent; $\delta$ : standard deviation; *: significance level less than $0.05 ; * *$ : significance level less than 0.01

\subsection{Mean intensity and status of parasites species recorded}

In the population of $O$. niloticus examined, parasite mean intensity is: low $(10 \leq \mathrm{I} \leq 50)$ for $M$. agolus, M. brachysporus, $M$. heterosporus and $M$. israelensis; very low $(\mathrm{I}<10)$ for $M$. cichlidarum and $M$. fotoi. When studying the parasite load in a single organ of $O$. niloticus, it appears that: M. heterosporus has a low mean intensity in the spleen, M. brachysporus and M. israelensis have a low mean intensity in the kidney and spleen while all other parasite species have a very low mean intensity in both organs (Table 1). No significant difference $(\mathrm{P}>0.05)$ was found in parasite load between the kidney and spleen. In the kidney, M. agolus and M. heterosporus had a standard deviation value higher than the mean intensity value (table 1), suggesting that spores of these parasite species are aggregated in the kidney of some host fish individuals. Furthermore, M. brachysporus and M. israelensis had a standard deviation value higher than the mean intensity value in the spleen (Table 1). So, there is spores aggregation of these parasite species in the spleen of some host fish individuals. As initially noticed with the rate of infection, the variation between parasite mean intensity was highly significant $(\mathrm{P}<0.01)$ in the kidney and spleen (Table 1). The result was idem after combining the number of spores of each parasite species from the kidney and spleen (Kidney + spleen) (Table 1). Comparing two by two, there was significant differences $(\mathrm{P}<0.05)$ in the variation of mean intensities between some parasite species. When combining the parasite load of the kidney and spleen, it appears that the mean intensity of $M$. cichlidarum and $M$. fotoi are on one hand statistically different from each other and on the other hand statistically lower than those of the other parasite species. The mean intensity of $M$. cichlidarum is statistically lower than those of the other parasite species in the kidney and spleen. The mean intensity of $M$. fotoi is statistically lower than those of M. agolus and M. brachysporus in the kidney, whereas it is statistically lower than those of M. brachysporus and M. israelensis in the spleen. 


\subsection{Variation of infection rate and mean intensity between organ portions}

This study reveals that, except $M$. foto $i$ with a statistically lower occurrence in the anterior portion of the kidney ( $\mathrm{P}$ $<0.05)$, the rate of infection of Myxosporidia species recorded did not vary significantly $(\mathrm{P}>0.05)$ between portions of the kidney and spleen (Table 2). However, in an organ portion, the variation of the infection rate between parasite species is highly significant $(\mathrm{P}<0.001)$. When comparing parasite species two by two, there is significant or high significant difference.

The mean intensity of parasites species recorded does not vary significantly between organ portions. However, an exception was made for M. agolus in the spleen. In fact, the number of spores of this parasite species is statistically $(\mathrm{P}<0.01)$ higher in the anterior portion of the spleen than in the medial and posterior portions of the same organ (Table 2).

Within an organ portion, the variation of the mean intensity between parasite species is highly significant $(\mathrm{P}<$ $0.01)$. In addition, within an organ portion, paired comparison revealed significant differences $(\mathrm{P}<0.05)$ between mean intensities of certain parasite species.

Table 2. Variation of infection rate and mean intensity of Myxosporidia species as function of organ portion of Oreochromis niloticus

\begin{tabular}{|c|c|c|c|c|c|c|c|c|c|c|c|c|c|}
\hline \multirow[t]{2}{*}{ Parasites species } & \multirow{2}{*}{ Epidemiological index } & \multicolumn{4}{|c|}{ Kidney } & \multicolumn{4}{|c|}{ Spleen } & \multicolumn{4}{|c|}{ Kidney + Spleen } \\
\hline & & $\begin{array}{l}\text { Anterior } \\
\text { portion }\end{array}$ & $\begin{array}{l}\text { Medial } \\
\text { portion }\end{array}$ & $\begin{array}{l}\text { Posterior } \\
\text { portion }\end{array}$ & $\begin{array}{l}\text { Value of the } \\
\text { statistical test }\end{array}$ & $\begin{array}{l}\text { Anterior } \\
\text { portion }\end{array}$ & $\begin{array}{l}\text { Medial } \\
\text { portion }\end{array}$ & $\begin{array}{l}\text { Posterior } \\
\text { portion }\end{array}$ & $\begin{array}{l}\text { Value of the } \\
\text { statistical test }\end{array}$ & $\begin{array}{l}\text { Anterior } \\
\text { portion }\end{array}$ & $\begin{array}{l}\text { Medial } \\
\text { portion }\end{array}$ & $\begin{array}{l}\text { Posterior } \\
\text { portion }\end{array}$ & $\begin{array}{l}\text { Value of the } \\
\text { statistical test }\end{array}$ \\
\hline \multirow[t]{2}{*}{ M. agolus } & $\operatorname{Pr}(\%)$ & 58.7 & 76.1 & 73.9 & $\chi^{2}=3.9$ & 52.17 & 54.3 & 54.3 & $\chi^{2}=0.058$ & 69.6 & 80.4 & 84.8 & $\chi^{2}=3.322$ \\
\hline & $\mathrm{I}\left(V_{\min }-V_{\max }\right) \delta$ & $2.8(1-8) 1.9$ & $3.4(1-17) 3.1$ & $3.9(1-32) 5.3$ & $H=0.544$ & $5.7(1-18) 3.9$ & $3(1-9) 1.9$ & $3.6(1-11) 2$ & $H=10.49 * *$ & $6.6(1-23) 4.9$ & $5.2(1-19) 4.3$ & $5.7(1-37) 5.9$ & $H=2.09$ \\
\hline \multirow[t]{2}{*}{ M. brachysporus } & $\operatorname{Pr}(\%)$ & 65.2 & 54.3 & 76.1 & $\chi^{2}=4.79$ & 71.7 & 69.7 & 60.9 & $\chi^{2}=1.385$ & 80.4 & 78.3 & 82.6 & $\chi^{2}=0.276$ \\
\hline & $\mathrm{I}\left(\mathrm{V} \min -V_{\max }\right) \delta$ & $3.4(1-10) 2.2$ & $5.2(1-20) 5$ & $5.8(1-22) 5.3$ & $\mathrm{H}=3.25$ & $6.8(1-59) 10.2$ & $4.6(1-15) 2.9$ & $4.3(1-15) 3.5$ & $H=1.81$ & $8.8(1-63) 10.8$ & $7.7(1-29) 6.5$ & $8.5(1-34) 7.5$ & $H=0.05$ \\
\hline \multirow[t]{2}{*}{ M. cichlidarum } & $\operatorname{Pr}(\%)$ & 13 & 8.7 & 15.2 & $\chi^{2}=0.939$ & 28.3 & 13 & 23.9 & $\chi^{2}=3.322$ & 39.1 & 15.2 & 26.1 & $\chi^{2}=6.721^{*}$ \\
\hline & $I(V \min -V \max ) \delta$ & $1.3(1-3) 0.8$ & $1.5(1-3) 1.0$ & $1.7(1-2) 0.4$ & $\mathrm{H}=2.18$ & $1.6(1-3)$ & $1.2(1-2)$ & $1.6(1-5)$ & $H=1.64$ & $1.6(1-4) 0.9$ & $1.8(1-5) 1.5$ & $2.5(1-7) 1.6$ & $\mathrm{H}=\mathbf{5}$ \\
\hline \multirow[t]{2}{*}{ M. fotoi } & $\operatorname{Pr}(\%)$ & 32.6 & 52.2 & 58.7 & $\chi^{2}=6.795^{*}$ & 50 & 41.3 & 45.6 & $\chi^{2}=0.701$ & 63 & 67.4 & 63 & $\chi^{2}=0.253$ \\
\hline & $\mathrm{I}\left(V_{\min }-V_{\max }\right) \delta$ & $2.2(1-5) 1$ & $2.9(1-13) 2.5$ & $2.9(1-9) 2.2$ & $P=0.907$ & $1.6(1-7) 1.6$ & $2.8(1-12) 2.8$ & $2.4(1-8) 1.7$ & $H=1.34$ & $3.3(1-9) 2$ & $3.9(1-25) 4.7$ & $4.4(1-16) 3.7$ & $H=1.54$ \\
\hline \multirow[t]{2}{*}{ M. heterosporus } & $\operatorname{Pr}(\%)$ & 39.13 & 45.6 & 50 & $\chi^{2}=1.113$ & 34.8 & 47.8 & 36.9 & $\chi^{2}=1.874$ & 50 & 58.7 & 54.3 & $\chi^{2}=0.701$ \\
\hline & $\mathrm{I}\left(\mathrm{V} \min -V_{\max }\right) \delta$ & $3.6(1-8) 1.9$ & $4.7(1-19) 4.8$ & $6.2(1-20) 5.1$ & $\mathrm{H}=3.95$ & $6.6(1-21) 6.1$ & $3.7(1-10) 2.3$ & $6.2(2-29) 6.5$ & $H=2.24$ & $7.3(1-25) 7$ & $6.7(1-21) 5.3$ & $9.9(2-40) 9$ & $H=2.69$ \\
\hline \multirow[t]{2}{*}{ M. israelensis } & $\operatorname{Pr}(\%)$ & 54.3 & 60.9 & 71.7 & $\chi^{2}=3.024$ & 50 & 54.3 & 47.8 & $\chi^{2}=0.406$ & 67.4 & 73.9 & 73.9 & $\chi^{2}=0.643$ \\
\hline & $I(V \min -V \max ) \delta$ & $3.6(1-12) 2.5$ & $4.4(1-14) 3.5$ & $4.8(1-17) 3.8$ & $\mathrm{H}=1.4$ & $5.8(1-31) 7.5$ & $5(1-31) 5.8$ & $4.6(1-29) 5.8$ & $H=0.62$ & $7.2(1-37) 8.5$ & $7.3(1-42) 7.7$ & $7.6(1-36) 6.9$ & $H=0.92$ \\
\hline \multirow[t]{2}{*}{ TOTAL } & $\operatorname{Pr}(\%)$ & 89.1 & 97.8 & 97.8 & $\chi^{2}=4.816$ & 86.9 & 93.5 & 89.1 & $\chi^{2}=1.113$ & 100 & 97.8 & 100 & $\chi^{2}=2.015$ \\
\hline & $I(V \min -V \max ) \delta$ & $9.1(1-22) 6.4$ & $12.1(1-58) 11.8$ & $16.1(2-57) 13.19$ & $\mathrm{H}=7.62 *$ & $17(1-79) 17$ & $11.3(1-53) 10.1$ & $11.8(2-48) 10.6$ & $\mathrm{H}=\mathbf{2 . 3 3}$ & $22.9(1-95) 21$ & $23(2-111) 19.6$ & $26.3(3-78) 19.7$ & $H=1.54$ \\
\hline Value of the & & $\chi^{2}=35.22 * *$ & $\chi^{2}=46.86^{* *}$ & $\chi^{2}=50.16^{* *}$ & & $\chi^{2}=21.25^{* *}$ & $\chi^{2}=33.32^{* *}$ & $\chi^{2}=15.93 * *$ & & $\chi^{2}=21.26^{* *}$ & $\chi^{2}=58.26^{* *}$ & $\chi^{2}=48.15^{* *}$ & \\
\hline statistical test & & $\mathrm{H}=86.57^{\text {** }}$ & $H=78.5^{* *}$ & $\mathrm{H}=87.05^{* *}$ & & $\mathrm{H}=27.21^{* *}$ & $H=25.28 * *$ & $H=21.93 * *$ & & $\mathrm{H}=38.83^{* *}$ & $H=22.4^{* *}$ & $H=25.45^{* *}$ & \\
\hline
\end{tabular}

M: Myxobolus; Pr: infection rate; I: mean intensity; Vmin: minimum value; Vmax maximum value; $\chi^{2}$ :

chi-squared test value; H: Kruskal-Wallis test value; U: Mann-Whitney test value; \%: percent; $\delta$ : standard deviation; *: significance level less than $0.05 ; * *$ : significance level less than 0.01

\subsection{Variation of infection rate and mean intensity of Myxosporidia species as function of size class of Oreochromis niloticus.}

All Myxobolus species recorded infect the kidney and spleen of $O$. niloticus specimens at different ages, except $M$. cichlidarum, which was not found in the kidney of young fish (Table 3). When combining infection of the kidney and spleen (kidney + spleen), it appears that, except $M$. heterosporus, the infection rate of all parasite species increase with host age. However, the increase of the infection rate with host age is statistically significant $(\mathrm{P}<0.05)$ for M. agolus only. Variation between parasite infection rates was statistically significant $(\mathrm{P}<0.05)$ in the spleen of the class size ]67-94], whereas in the kidney, a statistical significant difference was observed only in fish with standard length of [40 -67] and ]67 - 94].

The occurrence of M. agolus is statistically higher in the spleen of fish with $\mathrm{SL}=$ ] 67 - 94]. On the other hand, the kidney of fish individuals with SL $>94 \mathrm{~mm}$ are statistically more parasitized by M. cichlidarum (Table 3).

For all age groups, the mean intensity ranged from 1.5 (for M. cichlidarum) to 53.3 (for M. israelensis) spores. Although there is a variation in the mean intensity of all parasite species between age groups, no significant difference was recorded. Despite the fact that no significant difference was recorded, it should be noted that $M$. brachysporus forms more spores in the kidney and spleen of young $O$. niloticus specimens, whereas the greater number of spores of other Myxobolus species harvested in the present study was obtained in fish with SL $>94 \mathrm{~mm}$ (Table 3). 
Table 3. Variation of infection rate and mean intensity of Myxosporidia species as function of size class of Oreochromis niloticus

\begin{tabular}{|c|c|c|c|c|c|c|c|c|c|c|c|c|c|}
\hline \multirow{2}{*}{$\begin{array}{l}\text { Parasite } \\
\text { species }\end{array}$} & \multirow{2}{*}{$\begin{array}{l}\text { Epidemiological } \\
\text { index }\end{array}$} & \multicolumn{4}{|c|}{ Kidney } & \multicolumn{4}{|c|}{ Spleen } & \multicolumn{4}{|c|}{ Kidney + Spleen } \\
\hline & & {$[40-67]$} & ]67-94] & $\mathrm{SL}>94 \mathrm{~mm}$ & $\begin{array}{l}\text { Value of the } \\
\text { statistical test }\end{array}$ & {$[40-67]$} & ]67-94] & $\begin{array}{l}\mathrm{SL}>94 \\
\mathrm{~mm}\end{array}$ & $\begin{array}{l}\text { Value of the } \\
\text { statistical test }\end{array}$ & {$[40-67]$} & ]67-94] & $\mathrm{SL}>94 \mathrm{~mm}$ & $\begin{array}{l}\text { Value of } \\
\text { statistica }\end{array}$ \\
\hline \multirow[t]{2}{*}{ M. agolus } & $\operatorname{Pr}(\%)$ & 66.7 & 93.9 & 100 & $\chi^{2}=5.963$ & 33.3 & 81.8 & 75 & $\chi^{2}=8.22 *$ & 66.7 & 96.9 & 100 & $\chi^{2}=8.59$ \\
\hline & $\mathrm{I}(\mathrm{V} \min -\mathrm{V} \max ) \delta$ & $7.7(2-18) 5.6$ & $8(2-55) 9.8$ & $8(3-13) 5.2$ & $\mathrm{H}=\mathbf{0 . 3 9}$ & $7.3(5-11) 3.2$ & $8.8(2-21) 5.7$ & $\begin{array}{l}13.7(9- \\
17) 4.2\end{array}$ & $\mathrm{H}=2.5$ & $11.3(2-20) 6.8$ & $15.2(3-64) 12.8$ & $\begin{array}{l}18.2(3- \\
30) 12.6\end{array}$ & $\mathrm{H}=0.9$ \\
\hline \multirow[t]{2}{*}{ M. brachysporus } & $\operatorname{Pr}(\%)$ & 88.9 & 81.8 & 100 & $\chi^{2}=1.06$ & 77.8 & 84.8 & 100 & $\chi^{2}=1.060$ & 88.9 & 93.9 & 100 & $\chi^{2}=0.60$. \\
\hline & $\mathrm{I}(\mathrm{V} \min -\mathrm{Vmax}) \delta$ & $22.8(6-39) 17.7$ & $9.3(1-41) 8.5$ & $7.2(5-12) 3.2$ & $\mathrm{H}=3.58$ & $23.1(8-67) 21.9$ & $9.9(1-28) 7.8$ & $\begin{array}{l}12.5(4- \\
32) 13.2\end{array}$ & $\mathrm{H}=3.5$ & $39.6(4-106) 36.1$ & $17.1(2-62) 15.6$ & $\begin{array}{l}19.8(9- \\
38) 13.2\end{array}$ & $\mathrm{H}=3.9$ \\
\hline \multirow[t]{2}{*}{ M. cichlidarum } & $\operatorname{Pr}(\%)$ & 0 & 30.3 & 75 & $\chi^{2}=7.923^{*}$ & 22.2 & 51.5 & 75 & $\chi^{2}=3.728$ & 22.2 & 63.6 & 75 & $\chi^{2}=5.54$ \\
\hline & $\mathrm{I}(\mathrm{V} \min -\mathrm{V} \max ) \delta$ & 0 & $2.1(1-5) 1.2$ & $1.7(1-2) 0.5$ & $\mathrm{U}=13$ & $1.5(1-2) 0.7$ & $2.2(1-7) 1.5$ & $2.3(1-4) 1.5$ & $\mathrm{H}=\mathbf{0 . 4 5}$ & $1.5(1-2) 0.7$ & $2.7(1-12) 2.4$ & $4(2-6) 2$ & $\mathrm{H}=\mathbf{3 . 3}$ \\
\hline \multirow[t]{2}{*}{ M. fotoi } & $\operatorname{Pr}(\%)$ & 55.55 & 72.7 & 75 & $\chi^{2}=1.046$ & 44.4 & 66.7 & 100 & $\chi^{2}=3.876$ & 66.7 & 87.9 & 100 & $\chi^{2}=3.25$ \\
\hline & $\mathrm{I}\left(\mathrm{V}_{\min }-\mathrm{V}_{\max }\right) \delta$ & $6.6(1-12) 4.8$ & $4.9(1-18) 3.8$ & $10(3-22) 10.4$ & $\mathrm{H}=1.2$ & $3.2(1-5) 1.7$ & $4.9(1-14) 3.1$ & $\begin{array}{l}10.9(2- \\
22) 8.5\end{array}$ & $\mathrm{H}=3.7$ & $7.7(3-13) 4.2$ & $7.9(1-32) 6.8$ & $17.8(5-44) 18$ & $H=2$ \\
\hline \multirow[t]{2}{*}{ M. heterosporus } & $\operatorname{Pr}(\%)$ & 66.66 & 69.7 & 50 & $\chi^{2}=0.633$ & 55.5 & 69.7 & 25 & $\chi^{2}=3.328$ & 66.7 & 75.7 & 50 & $\chi^{2}=1.30$ \\
\hline & $\mathrm{I}\left(\mathrm{V} \min -V_{\max }\right) \delta$ & $11(2-36) 11$ & $8.4(1-41) 8.4$ & $8(3-13) 8$ & $\mathrm{H}=\mathbf{0 . 0 7}$ & $11.4(3-26) 9.8$ & $9.5(1-38) 9.9$ & 17 & $\mathrm{H}=1.6$ & $20.5(2-62) 22.1$ & $16.5(1-66) 16.7$ & $31(30-32) 1.4$ & $\mathrm{H}=3.2$ \\
\hline \multirow[t]{2}{*}{ M. israelensis } & $\operatorname{Pr}(\%)$ & 77.8 & 78.8 & 100 & $\chi^{2}=1.070$ & 44.4 & 72.7 & 100 & $\chi^{2}=4.588$ & 77.8 & 78.8 & 100 & $\chi^{2}=1.07$ \\
\hline & $\mathrm{I}(\mathrm{V} \min -\mathrm{Vmax}) \delta$ & $8.8(6-12) 2.4$ & $9.3(1-32) 8$ & $16.8(1-41) 19$ & $\mathrm{H}=0.4$ & $9(4-16) 5.3$ & $7.4(1-15) 4.6$ & $\begin{array}{l}36.5(1- \\
91) 39.2\end{array}$ & $\mathrm{H}=3.1$ & $13.9(5-28) 8.4$ & $16.2(2-45) 10.9$ & $\begin{array}{l}53.3(3- \\
114) 51.9\end{array}$ & $\mathrm{H}=1.4$ \\
\hline \multirow[t]{2}{*}{ TOTAL } & $\operatorname{Pr}(\%)$ & 100 & 100 & 100 & & 100 & 100 & 100 & & 100 & 100 & 100 & \\
\hline & $\mathrm{I}\left(\mathrm{V} \min -V_{\max }\right) \delta$ & $40.1(7-110) 39.4$ & $32.5(3-103) 24.8$ & $52(13-103) 42.6$ & $\mathrm{H}=0.66$ & $36.6(5-89) 28.2$ & $32(2-96) 22.4$ & $\begin{array}{l}75.5(7- \\
139) 54.1\end{array}$ & $\mathrm{H}=2.8$ & $72.7(10-169) 59.5$ & $64.6(8-154) 40.9$ & $\begin{array}{l}127.5(20- \\
242) 93.8\end{array}$ & $\mathrm{H}=2.1$ \\
\hline Value of the & & $\chi^{2}=18.1^{* *}$ & $\chi^{2}=38.06^{* * *}$ & $\chi^{2}=6$ & & $\chi^{2}=6.62$ & $\chi^{2}=11.45^{*}$ & $\chi^{2}=10.35$ & & $\chi^{2}=10.15$ & $\chi^{2}=18.18^{* *}$ & $\chi^{2}=8$ & \\
\hline statistical test & & $\mathrm{H}=3.89$ & $\mathrm{H}=20.35^{* * k}$ & $H=5.59$ & & $\mathrm{H}=13.89^{*}$ & $H=26.78^{* * *}$ & $\mathrm{H}=6.13$ & & $\mathrm{H}=11.98^{*}$ & $\mathrm{H}=42.88^{* * k}$ & $H=6.65$ & \\
\hline
\end{tabular}

M.: Myxobolus; Pr: infection rate; I: mean intensity; Vmin: minimum value; Vmax maximum value; $\chi^{2}$ :

chi-squared test value; H: Kruskal-Wallis test value; U: Mann-Whitney test value; \%: percent; $\delta$ : standard deviation; *: significance level less than $0.05 ; * *$ : significance level less than 0.01

\subsection{Variation of infection rate and mean intensity of Myxosporidia species as function of sex of Oreochromis niloticus}

The infection rate of M. agolus and M. fotoi are statistically higher in the kidney of female fish $(\mathrm{P}<0.05)$. On the other hand, M. agolus, M. brachysporus and M. heterosporus are significantly more common in the spleen of female fish. Myxobolus cichlidarum and M. israelensis appear to be more common in female fish but the difference is not significant $(\mathrm{P}>0.05)$ (Table 4).

Table 4. Variation of infection rate and mean intensity of Myxosporidia species as function of sex of Oreochromis niloticus

\begin{tabular}{|c|c|c|c|c|c|c|c|c|c|c|}
\hline \multirow{2}{*}{$\begin{array}{l}\text { Parasites } \\
\text { species }\end{array}$} & \multirow{2}{*}{$\begin{array}{l}\text { Epidemiological } \\
\text { index }\end{array}$} & \multicolumn{3}{|c|}{ Kidney } & \multicolumn{3}{|c|}{ Spleen } & \multicolumn{3}{|c|}{ Kidney + Spleen } \\
\hline & & $\begin{array}{l}\text { Male } \\
(\mathrm{nl}=16)\end{array}$ & $\begin{array}{l}\text { Female } \\
(\mathrm{n} 2=30)\end{array}$ & $\begin{array}{l}\text { Value of the } \\
\text { statistical test }\end{array}$ & $\begin{array}{l}\text { Male } \\
(\mathrm{nl}=16)\end{array}$ & $\begin{array}{l}\text { Female } \\
(\mathrm{n} 2=30)\end{array}$ & $\begin{array}{l}\text { Value of the } \\
\text { statistical test }\end{array}$ & $\begin{array}{l}\text { Male } \\
(\mathrm{n} 1=16)\end{array}$ & $\begin{array}{l}\text { Female } \\
(\mathrm{n} 2=30)\end{array}$ & $\begin{array}{l}\text { Value of the } \\
\text { statistical test }\end{array}$ \\
\hline \multirow[t]{2}{*}{ M. agolus } & $\operatorname{Pr}(\%)$ & 75 & 96.7 & $\chi^{2}=5.06^{*}$ & 43.7 & 86.7 & $\chi^{2}=9.48$ * & 75 & 100 & $\chi^{2}=8.21^{*}$ \\
\hline & $\mathrm{I}(\mathrm{V} \min -\mathrm{V} \max ) \delta$ & $5.3(2-10) 2.7$ & $9(2-55) 10.3$ & $\mathrm{U}=\mathbf{1 3 6}$ & $7.3(2-16) 4.8$ & $9.7(2-21) 5.7$ & $\mathrm{U}=68$ & $9.6(2-26) 7.1$ & $17.1(3-64) 13$ & $\mathrm{U}=105.5^{*}$ \\
\hline \multirow[t]{2}{*}{ M. brachysporus } & $\operatorname{Pr}(\%)$ & 87.5 & 83.3 & $\chi^{2}=0.14$ & 62.5 & 96.7 & $\chi^{2}=9.442^{*}$ & 87.5 & 96.7 & $\chi^{2}=1.438$ \\
\hline & $\mathrm{I}\left(V_{\min }-V_{\max }\right) \delta$ & $11.5(1-39) 13.2$ & $11(2-41) 9.8$ & $\mathrm{U}=\mathbf{1 4 8 . 5}$ & $19.3(1-67) 20.1$ & $10.2(1-32) 7.9$ & $\mathrm{U}=\mathbf{1 0 7}$ & $25.3(2-106) 25.3$ & $19.7(2-62) 19.7$ & $\mathrm{U}=\mathbf{1 8 5}$ \\
\hline \multirow[t]{2}{*}{ M. cichlidarum } & $\operatorname{Pr}(\%)$ & 12.5 & 36.7 & $\chi^{2}=3.006$ & 31.2 & 56.7 & $\chi^{2}=0.701$ & 31.2 & 66.7 & $\chi^{2}=3.61$ \\
\hline & $\mathrm{I}(\mathrm{V} \min -\mathrm{Vmax}) \delta$ & $1(1-1)$ & $2.2(1-5) 1.2$ & $\mathrm{U}=3$ & $1.6(1-3) 0.9$ & $2.2(1-7) 1.6$ & $\mathrm{U}=32$ & $1.7(1-4) 1.2$ & $3.1(1-12) 2.4$ & $\mathrm{U}=\mathbf{2 9}$ \\
\hline \multirow[t]{2}{*}{ M. fotoi } & $\operatorname{Pr}(\%)$ & 50 & 80 & $\chi^{2}=4.43^{*}$ & 62.5 & 66.7 & $\chi^{2}=0.08$ & 75 & 90 & $\chi^{2}=1.82$ \\
\hline & $\mathrm{I}(\mathrm{V} \min -\mathrm{V} \max ) \delta$ & $5.5(1-12) 4.3$ & $5.8(1-22) 5.1$ & $\mathrm{U}=95.5$ & $3(1-7) 1.9$ & $6.6(1-22) 4.7$ & $\mathrm{U}=41^{*}$ & $6.2(1-19) 5.4$ & $10(1-44) 9.4$ & $\mathrm{U}=117$ \\
\hline \multirow[t]{2}{*}{ M. heterosporus } & $\operatorname{Pr}(\%)$ & 56.2 & 73.3 & $\chi^{2}=1.38$ & 43.7 & 73.3 & $\chi^{2}=1^{*}$ & 56.2 & 80 & $\chi^{2}=2.9$ \\
\hline & $\mathrm{I}\left(\mathrm{V} \min -V_{\max }\right) \delta$ & $4.9(1-13) 3.9$ & $11.8(1-41) 11.6$ & $\mathrm{U}=\mathbf{5 8}$ & $6.3(1-17) 5.6$ & $11.3(1-38) 10.5$ & $\mathrm{U}=\mathbf{5 7}$ & $9.8(2-26) 8.4$ & $21.2(1-66) 18.8$ & $U=67.5$ \\
\hline \multirow[t]{2}{*}{ M. israelensis } & $\operatorname{Pr}(\%)$ & 68.8 & 86.7 & $\chi^{2}=2.12$ & 56.2 & 76.7 & $\chi^{2}=2.054$ & 68.8 & 86.7 & $\chi^{2}=2.12$ \\
\hline & $\mathrm{I}\left(\mathrm{V} \min -V_{\max }\right) \delta$ & $6.9(2-13) 3.6$ & $11.3(1-41) 10.5$ & $\mathrm{U}=124.5$ & $5.8(1-16) 4.8$ & $13.4(1-91) 18.5$ & $\mathrm{U}=62.5$ & $11.6(3-28) 7.6$ & $23.2(2-114) 24.4$ & $\mathrm{U}=94.5$ \\
\hline \multirow[t]{2}{*}{ TOTAL } & $\operatorname{Pr}(\%)$ & 100 & 100 & & 100 & 100 & & 100 & 100 & \\
\hline & $\mathrm{I}\left(\mathrm{V} \min -V_{\max }\right) \delta$ & $24.4(3-80) 21$ & $41.7(8-110) 30.3$ & $U=143^{*}$ & $25.2(2-89) 27.1$ & $42.5(9-139) 28.7$ & $\mathrm{U}=124.5^{*}$ & $48.1(8-169) 47.5$ & $84.3(19-242) 50.7$ & $U=122^{* *}$ \\
\hline Value of the & & $\chi^{2}=22.45^{* *}$ & $\chi^{2}=35.71 * *$ & & $x^{2}=5$ & $\chi^{2}=16.65^{* *}$ & & $\chi^{2}=11.06$ & $\chi^{2}=19.04$ ** & \\
\hline statistical test & & $H=7.99$ & $H=24.84^{\text {** }}$ & & $H=17.1^{* *}$ & $H=28.12^{\text {** }}$ & & $H=16.85^{* *}$ & $H=43.75^{* *}$ & \\
\hline
\end{tabular}

M: Myxobolus; $\mathrm{n} 1$ : number of male fish individual; $\mathrm{n}$ : number of female fish individual; Pr: infection rate; I: mean intensity; Vmin: minimum value; Vmax maximum value; $\chi^{2}$ : chi-squared test value; H: Kruskal-Wallis test value; U: Mann-Whitney test value; \%: percent; $\delta$ : standard deviation; *: significance level less than $0.05 ; * *$ : significance level less than 0.01 
In general, fish sex does not influence parasite load. However, there was an exception with M. fotoi. In fact, the average intensity of this parasite species is significantly $(\mathrm{P}<0.05)$ higher in the spleen of females fish (Table 4). The mean intensities of M. agolus, M. cichlidarum, M. heterosporus and M. israelensis appear to be higher in the kidney and spleen of female fish, but the difference is not significant $(\mathrm{P}>0.05)$. In contrast, the mean intensity of $M$. brachysporus seems to be higher in the kidney and spleen of male fish, but the difference is not significant (Table 4).

\section{Discussion}

\subsection{Diversity of Myxosporidia havested}

In $O$. niloticus specimens examined in the present study, all parasites species recorded belong to the genus Myxobolus Bütschli, 1882. Among Myxosporidia, this genus is numerically the most important group because, out of about 2300 species of Myxosporidia described around the world (Fiala et al., 2015), there are about 905 described species of the genus Myxobolus (Eiras et al., 2005, 2014). Polyparasitism is a well-documented phenomenon in freshwater fish (Fomena, 1995; Abakar-Ousman, Fomena, Ngassam and Bouix, 2006; Fomena, Lekeufack and Bouix, 2008, Fonkwa et al., 2018). With six parasite species harvested, this phenomenon was noticed in the population of $O$. niloticus examined. The rarity of inter and intraspecific competitions in Myxosporidia (Lom \& Dyková, 1992) is a possible cause of polyparasitism. Similar observation was made by Fomena et al. (1993) in the Melen fish pond in Cameroon, Abakar-Ousman (2006) in the river Chari in Chad and Nchoutpouen (2015) in the Noun Basin in Cameroon. Only polyspecific infection was observed in the examined $O$. niloticus specimens. The number of parasite species carried by a host individual ranged from 2 to 6 . This situation seems normal because opportunities for Myxoxporidia infections are higher in fish pond than in the natural environment (Nchoutpouen and Fomena, 2011). In fact, in rearing situation, by increasing the density and confinement of the fish hosts, the physicochemical conditions of the environment are modified and become more favourable for the installation of pathogenic agents (Boungou, Simaré, Mano and Kabré, 2013). In addition, the weakening of the immune response of host individuals by the first parasite species to settle can also favor host colonization by other parasite species (Nchoutpouen, 2015).

\subsection{Geographic distribution of recorded Myxobolus species}

Myxosporidia species recorded affect exclusively cichlid hosts. They were initially described in Israel (M. agolus, M. israelensis); in Chad (M. cichlidarum) and in Uganda (M. brachysporus and M. heterosporus). These parasite species were probably introduced in Cameroon during the transfer of fish for rearing purposes. (1) Myxobolus agolus was first described in the kidney and spleen of $O$. niloticus valcani, $O$. aureus $\times O$. niloticus hybrids in Israel. Obiekezie \& Okaeme (1990) found this parasite species in the spleen of O. niloticus, Sarotherodon galilaeus and Tilapia guineensis in Nigeria. In Cameroon, their spores were found in the kidney and spleen, while cysts were found on the gills of $O$. niloticus (Fomena et al., 1993, Nchoutpouen, 2015). In Chad, this species of myxosporidia has been reported on the gills, liver, kidney and spleen of O. niloticus and Sarotherodon galilaeus (Abakar-Ousman, 2006). (2) M. brachysporus, is a parasite originally described in the spleen of Tilapia esculenta, T. variabilis and Haplochromis sp. in Uganda. Obiekezie and Okaeme (1990) reported its presence in the kidney and spleen of Tilapia guineensis, O. niloticus and Sarotherodon galilaeus in Nigeria. Fomena et al. (1993) and Nchoutpouen (2015) found this parasite in the kidney and spleen of O. niloticus in Cameroon. Kabré (1997) identifies M. brachysporus in the liver and kidney of O. niloticus in Burkina-Faso. Abakar Ousman (2006) found their spores in the liver, kidney and spleen of O. niloticus and S. galilaeus in Chad. (3) Before the present study, Myxobolus cichlidarum was known only from $O$. niloticus and $S$. galilaeus in Chad. In these host species, it forms cysts in the fins, eyes and gills. In addition, diffuse spores were observed in the liver, kidney and spleen. (4) Since its original description in Cameroon on the gills of O. niloticus (Fomena et al., 1993), M. fotoi had not yet been found in another country. (5) The original description of Myxobolus heterosporus was given in Uganda in the viscera of Tilapia esculenta, T. variabilis, Tilapia sp., O. niloticus and the spleen of Haplochromis sp.. Landsberg (1985) found the cysts of this parasite in the liver and spleen, and spores in the kidney of $O$. esculenta and $O$. variabilis in Israel. Sakiti, Blanc, Marques and Bouix (1991) reported the presence of this parasite in various organs of S. melanotheron, T. zillii and H. fasciatus in Benin. Their spores have been found in the kidney and spleen of O. niloticus in Cameroon (Fomena et al., 1993, Nchoutpouen, 2015). Kabré (1997) have reported the presence of this parasite in the liver and kidney of O. niloticus in Burkina Faso. Abakar Ousman (2006) describes this Myxosporidia species in the kidney, spleen and liver of O. niloticus and S. galilaeus in Chad. (6) Myxobolus israelensis has been described for the first time in the kidney and spleen of S. galilaeus, O. niloticus vulcani and the hybrid of O. aureus x O. niloticus in Israel. Obiekezie \& Okaeme (1990) found this parasite in the kidney and spleen of $O$. niloticus, $S$. galilaeus, the hybrid of $O$. niloticus $\times S$. galilaeus, and $T$. guinensis in Nigeria. Fomena et al. (1993), Fomena (1995), Nchoutpouen (2015) report the presence of M. israelensis on the gills, kidney and 
spleen of O. niloticus, S. galilaeus, T. mariae and T. cameronensis in Cameroon. Kabre (1997) reported the presence of this parasite species in the liver and kidney of O. niloticus in Burkina Faso. Abakar Ousman (2006) also found this species of Myxobolus in the liver, kidney and spleen of O. niloticus and S. galilaeus in Chad.

\subsection{Ecological status of harvested Myxobolus species and Variation of their epidemiological index between organs portions}

Parasites species harvested in the present study appeared frequent (prevalence $>50 \%$ ), this observation confirms the fact that $O$. niloticus is a normal host for all recorded parasites species. This result corroborates the observations of Obiekezie and Okaeme (1990) in Nigeria and Abakar-Ousman (2006) in Chad. Probably, the high prevalence of infection noticed for all studied myxosporidia species in the kidney and spleen of $O$. niloticus is associated with diminished defense capacity of these hematopoietic organs.

Molnár (1994) suggested that myxosporeans are parasites with species, organ and tissue specificity, and this tissue specificity is of decisive importance as a given myxosporean species can develop only in a certain tissue. The low mean intensities observed for $M$. cichlidarum and $M$. fotoi may be due to the fact that, being histozoïc Myxosporidia (Fomena et al., 1993; Abakar-Ousman, 2006), the cysts of M. cichlidarum and M. fotoi could be implanted in organs other than the kidneys and the spleen but the spores were carried and accumulated there by the host macrophages. Molnár and Kovács-Gayer (1985) observed that, following a heavy infection by the muscle-dwelling Myxobolus cyprini Doflein, 1898, large groups of spores were accumulated in melanomacrophage centres of the kidney. According to the observations of Dyková (1984), melanomacrophages play an important role in host's defense reactions. They appear capable, in some cases, of attacking small cysts and, typically, large mature spores, which are transported to the melanomacrophage centers of hematopoietic organs, where the parasites are isolated and gradually destroyed.

The kidney and spleen are common sites of establishment for various myxosporidia species infecting fishes and both coelozoic and histozoic stages of myxosporidia caused noticeable kidney and spleen pathology and are frequently responsible of fish diseases. It is always difficult to provide a proper diagnosis to determine whether spores developed in the kidney and spleen or whether they were carried there by the blood stream and captured by macrophage cells. The present study revealed that no species of myxosporidia recorded have a strict preference according to the anterior, medial or posterior portion of infected organs. However, Molnar (2007) believed that Myxozoans developing in fish kidney show a high affinity for different functional regions of this organ. Some are coelozoic in the lumen of the urinary ducts; others develop in the tubular epithelium, the endothelium of the renal corpuscles, or the hematopoietic tissue of the renal interstitium. For other myxozoans, the kidney serve only as a depot, where spores from the bloodstream are collected, stored and destroyed by melanomacrophage centers in the interstitium. All types of tissues in the kidney can then be infected by myxosporidia. There are no data about the site selection of myxosporidia species in the spleen, and in many cases, only scattered spores found among this hematopoietic organ have been reported.

\subsection{Variation of epidemiological index as function of size class and sex of Oreochromis niloticus}

During our investigations, the rate of infection of myxosporidia species in different age groups of $O$. niloticus showed, in agreement with Lekeufack and Fomena (2013), the existence of heterogeneity in the colonization of fish hosts by different parasite species. In general, all age group are susceptible to parasitism. The exception is made with M. cichlidarum whose spores were absent in the kidney of the younger $O$. niloticus individuals. This observation confirms that for M. cichlidarum, which is an histozoic species (Abakar-Ousman et al., 2006), the kidney serve only as a depot organ, where spores from the bloodstream are collected, stored and destroyed in melanomacrophage centers (Dyková, 1984). In addition, the infection rate of M. agolus increases with fish age. This fact appeared as a consequence of the accumulation of myxosporidia spores in the fish host organs with age. This is possible because parasites species located in internal organs can only release their different infesting stages after the death of the host individual. Our results corroborate those of Nchoutpouen et al. (2011) who pointed out that, in farming situation, older $O$. niloticus are more infested by M. agolus, M. brachysporus, M. heterosporus, $M$. israelensis and $M$. sarigi than the younger ones. However, the most common tendency is the decreasing of the infection rate with the size (age) of fish. So, Abakar-Ousman (2006), Lekeufack and Fomena (2013), Tombi and Bilong Bilong (2004), found that young fishes were more vulnerable to Myxozoans infections. The same observation was made by Brummer - Korvenkontio, Valtonen and Pugachev (1991) in Finland where the prevalence of infection of Rutilus rutilus by Myxobolus rhodei and M. pseudodispar decreased with the fish age. These authors explained their observations by the increase of the immune system response with the size of fish. Given the involvement of Oligochaeta in the developmental cycle of several myxosporidia species (Lom and Dyková, 2006), the variation between the rates of infection of parasite species harvested in the 
kidney and spleen within the size classes can be attributed to the proximity of fish (intermediate hosts) and Oligochaetes (definitive hosts). This variation does not imply any competition effect between parasite species because Sitja-Bobadilla (2008) reports the absence of inter and intraspecific competition between Myxosporidia species. This can also be due to the fact that sporogenesis of some myxosporidia species harvested in this study would occur in the kidney and spleen while that of other species would occur in other organs and spores would be transported in these hematopoietic organs.

Infection rate of M. agolus and M. fotoi was higher in the kidney of female fishes when compared with that in males. Furthermore, infection rate of M. agolus, M. brachysporus and M. heterosporus was higher in the spleen of female fishes. These differences in infection may be attributed to the immune response of the host due to the difference in endocrine glands activities between the male and female host fishes, which have been suggested by many authors (Donaldson and Fagerlund, 1970; Poulin, 1996; Gbankoto, Pampoulie, Marques and Sakiti, 2001). The higher infection rate in female $O$. niloticus may be related to investment in reproduction of females, which is more costly than that in males, thus female are more susceptible to parasite infection in periods of investment in gonad development (Simkova, Jarkovsky, Koubkova, Barus and Prokes, 2005). However, Poulin (1996) concluded that the infection rate difference according to sex is irrelevant and Simkova et al. (2005) believed that the effect of host sex on epidemiological indices is a not a clear phenomenon.

\section{Conclusion}

The study revealed the presence of Myxobolus agolus; M. brachysporus; M. cichlidarum; M. fotoi; M. heterosporus and $M$. israelensis in both the kidney and spleen of $O$. niloticus. These parasites species are known to affect exclusively cichlid fish. There is heterogeneity in the colonization of fish hosts by some recorded parasite species. The results of this study showed that some protocols for the diagnosis of myxosporidiosis are to be considered. Thus, the diagnosis of M. cichlidarum and M. agolus should be made in older specimens of $O$. niloticus. In addition, the diagnosis of M. agolus and M. fotoi should preferably be made in the kidney of female fish while the diagnosis of M. agolus, M. brachysporus and M. heterosporus should be done in the spleen of female fish.

\section{Acknowledgement}

The authors are thankful to the Faculty of Science, University of Yaounde I, Yaounde - Cameroon, for providing all the facilities to complete this work.

\section{References}

Abakar-Ousman, A. F. (2006). Myxosporidia (Myxozoa: Myxosporea) parasites of Chad freshwater fish: fauna and biology of the parasites species of Oreochromis niloticus (Linné, 1758) and Sarotherodon galilaeus (Linné, 1758) (Cichlidae) (Unpublished doctoral dissertation). University of Yaounde I, Yaounde, Cameroon.

Abakar-Ousman, A. F., Ngassam P., \& Bouix, G. (2006). Myxosporidian (Myxozoa) parasites of fresh water fish teleostean from Chad: New or few known species. Annales Université de N'Djamena, 1, 111-121.

Agius, C., \& Roberts, R. J. (2003). Melano-macrophage centres and their role in fish pathology. Journal of fish diseases, 26(9), 499-509. DOI: 10.1046/j.1365-2761.2003.00485.x

Baker, J. R., (1963). Three new species of Myxosoma (Protozoa: Myxosporidia) from East African freshwater fish. Parasitology, 53(1-2), 285-292. DOI: 10.1017/S003118200007275

Bilong Bilong, C. F., \& Njine, T. (1998). Population dynamics of three monogenes parasites of Hemichromis fasciatus Peters, 1858 in Yaounde municipal lake, and possible interest in intensive fish farming. Annals of the Faculty of science, University of Yaounde 1, 34, 295 - 303.

Boungou, M., Sinaré, Y., Mano K., \& Kabré, G. B. (2013). Parasitic Copepods (Arthropoda, Crustacea, Copepoda) from Fishes in Burkina Faso, Africa. International Journal of Fisheries and Aquatic Studies, 2(3), 58-64.

Brummer - Korvenkontio, H., Valtonen, E. T., \& Pugachev, O. N. (1991). Myxosporea parasites in roach, Rutilus rutilus (Linnaeus), from four lakes in central Finland. Journal of Fish Biology, 38(4), 573 - 586. http://doi.org/10.1111/j.1095-8649.1991.tb03144.x

Bush, A. O., Lafferty, K. D., Lotz J. M., \& Shostak, A. W. (1997). Parasitology meets ecology on its own terms. The Journal of parasitology, 83, 575-583. 
Donaldson, E. M., \& Fagerlund, U. H. (1970). Effect of sexual maturation and gonadectomy at sexual maturity on cortisol secretion rate in sockeye salmon (Oncorhynchus nerka). Journal of the Fisheries Board of Canada, 27(12), 2287-2296. http://doi.org/10.1139/f70-256

Dyková, I. (1984). The role of melanomacrophage centres in the tissue reaction to myxosporean infections of fishes cyprinic species, myxosporeans, Sphaerospora renicola, Mitraspora cyprini, Thelohanellus, Hoferellus cyprini, Myxobolus. Bulletin of the European Association of Fish Pathologists, 4, 65

Eiras, J. C., Molnár, K., \& Lu, Y.S. (2005). Synopsis of the species of Myxobolus Bütschli, 1982 (Myxozoa: Myxosporea: Myxobolidae). Systematic parasitology, 61(1), 1-46. http://doi.org/10.1007/s11230-004-6343 $-9$

Eiras, J. C., Zhang J. \& Molnar, K. (2014). Synopsis of the species of Myxobolus Butschli, 1882 (Myxozoa: Myxosporea, Myxobolidae) described between 2005 and 2013. Systematic Parasitology, 88(1), 11-36.

Fiala, I., Bartošová-Sojková, P., \& Whipps, C. M. (2015). Classification and phylogenetics of Myxozoa. In Myxozoan evolution, ecology and development (pp. 85-110). Springer, Cham.

Fomena, A., (1995). Myxosporidia and Microsporidia of fresh water fishes in Southern Cameroon: Faunal description, ultrastructure and biology (Unpublished doctoral dissertation), University of Yaounde I, Yaounde, Cameroon.

Fomena, A., Marques, A., \& Bouix, G. (1993). Myxosporidea (Myxozoa) of Oreochromis niloticus (Linnaeus, 1757) (Teleost, Cichlidae) in fish-farming pools at Melen (Yaounde, Cameroon, central Africa). Journal of African Zoology, 197, 45 - 56.

Fomena, A., Lekeufack Folefack G. B., \& Bouix, G. (2008). Three new species of Henneguya (Myxozoa: Myxosporea), parasites of fresh water fishes in Cameroon (central Africa). Journal of Afrotropical Zoology, 4, 93-103.

Fonkwa, G, Lekeufack, F. G. B., Tchuinkam, T., Ishtiyaq, A. \& Tchoumboue, J. (2018). Effect of Season on Myxosporean infections in Oreochromis niloticus Linnaeus, 1758 (Cichlidae) at MAPE Dam in Adamawa, Cameroon. Journal of Aquaculture Research \& Development, 9, 533. http://doi.org/10.4172/2155-9546. 1000533

Gbankoto, A., Pampoulie, C., Marques, A., \& Sakiti, G. N. (2001). Occurrence of myxosporean parasites in the gills of two tilapia species from Lake Nokoué (Bénin, West Africa): effect of host size and sex, and seasonal patterns of infection. Diseases of aquatic organisms, 44(3), 217 - 222. http://doi.org/10.3354/d ao044217

Kabre, G. B. (1997). fish Parasites of Burkina-Faso: Faunistic, ultrastructure, biolgy (Unpublished doctoral dissertation). University of Ouagadougou, Ouagadougou, Burkina-Faso.

Landsberg, J. H. (1985). Myxosporean infections in cultured tilapias in Israel. The Journal of protozoology, 32(1), 194-201. http://doi.org/10.1111/j.1550-7408.1985.tb03038.x

Lekeufack Folefack, G. B., \& Fomena, A. (2013). Structure and dynamics of infracommunities of Myxosporidia parasites of Ctenopoma petherici GÜNTHER, 1864 (Anabantidae), Clarias pachynema BOULENGER, 1903 (Clariidae) and Hepsetus odoe (Bloch, 1794) (Hepsetidae) in the Sangé River in Cameroon. International Journal of Biological and Chemical Sciences, 7(6), 2301-2316.

Lom, J., \& Arthur, J. R. (1989). A guideline for the preparation of species descriptions in Myxosporea. Journal of Fish Diseases, 12(2), 151 - 156. http://doi.org/10.1111/j.1365-2761.1989.tb00287.x

Lom, J., \& Dyková, I. (1992). Myxosporidia (Phylum Myxozoa). In: Protozoan parasites of fish (pp 159 - 235), Elsevier science publishers.

Lom, J., \& Dyková, I. (2006). Myxozoan genera: definition and notes on taxonomy, life- cycle terminology and pathogenic species. Folia parasitologica, 53(1), 1-36. http://doi.org/10.14411/fp.2006.001

Molnár, K. (1994). Comments on the host, organ and tissue specificity of fish myxozoans and on the types of their intrapiscine development. Parasitologia Hungarica, 27, 5-20.

Molnár, K. (2002). Site preference of myxosporeans in the gill. Diseases of Aquatic Organisms, 48(3), 197-207. DOI: $10.3354 /$ dao0 48197

Molnár, K. (2007). Site preference of myxozoans in the kidney of Hungarian fishes. Diseases of aquatic organisms, 78(1), 45-53. http://doi.org/10.3354/dao01827 
Molnár, K., \& Kovács - Gayer, É. (1985). The pathogenicity and development within the host fish of Myxobolus cyprinid Doflein. 1898. Parasitology, 90(3), 549 - 555. http://doi.org/10.1017/S0031182000055530

Nchoutpouen, E. (2015). Myxosporidia (Myxozoa: Myxosporea) parasites of some Teleost of the Noun Basin (West Region, Cameroon): taxonomy and biology of species parasitizing Oreochromis niloticus Linneaus, 1758 and Labeo parvus Boulenger, 1902 (Unpublished doctoral dissertation). University of Yaounde I, Yaounde, Cameroon.

Nchoutpouen, E., \& Fomena, A. (2011). The study of three new species of Myxobolus (Myxosporea: Myxobolidae) parasites of Labeo parvus Boulenger, 1902, Cyprinid fish in Cameroon. Journal of Applied Bioscience, 38, 2508-2517.

Obiekezie, A. I., \& Okaeme, A. N. (1990). Myxosporea (Protozoa) infections of cultured tilapias in Nigeria. Journal of African Zoology, 104, 77 - 91.

Press, C. M. (1998). Immunology of fishes. In: Handbook of vertebrate immunology, Pastoret, P.P., P. Griegel, H. Bazin and A. Govaerts $(E d s)$. Academic Press.

Poulin, R. (1996). Sexual inequalities in helminth infections: a cost of being a male? The American Naturalist, 147(2), 287 - 295. http://doi.org/10.1086/285851

Sakiti, N., Blanc, E., Marques, A., \& Bouix, G. (1991). Myxobolus spp. (Myxozoa, Myxosporea) Butschli, 1882 parasite on Cichlidae of Lake Nokoue in Benin (West Africa). Revue de zoologie africaine, 105(3), $173-186$.

Simkova, A., Jarkovsky, J., Koubkova, B., Barus, V., \& Prokes, M. (2005). Associations between fish reproductive cycle and the dynamics of Metazoan parasite infection. Parasitology Research, 95(1), 65-72. http://doi.org/10.1007/s00436-004-1261-y

Sitjà-Bobadilla, A. (2008). Fish immune response to Myxozoan parasites. Parasite, 15, 420-425. http://doi.org/10.1051/parasite/2008153420

Stiassny, M. L. G., Teugels, G. G., and Hopkins, C. D. (2007). Freshwater and Brackish Fish from Lower Guinea, Western Central Africa. In: Tropical Fauna and Flora Collection, IRD (Ed.). Institute of Research for Development, Paris, France.

Tombi, J., \& Bilong Bilong, C. F. (2004). Distribution of gill parasites of the freshwater fish Barbus martorelli Roman, 1971 (Teleostei: Cyprinidae) and tendency to inverse intensity evolution between Myxosporidia and Monogenea as a function of the host age. Revue d'élevage et de médecine vétérinaire des pays tropicaux, 57(1-2), 71-76. http://doi.org/10.19182/remvt.9909

Trewavas, E. (1983). Tilapiine fishes of the genera Sarotherodon, Oreochromis and Danakilia. British Museum (Natural History).

Valtonen, E. T., Holmes J.C. \& Koskivaara, M. (1997). Eutrophication, pollution and fragmentation: effects on parasite communities in roach (Rutilus rutilus) and perch (Perca fluviatilis) in four lakes in central Finland. Canadian Journal of Fisheries and Aquatic Sciences, 54(3), 572 - 585. http://doi.org/10.1139/f96-306

Welcomme, R. L. (1988). International introductions of inland aquatic species. Fisheries Technical ( $\left.\mathrm{N}^{\circ} 294\right)$. Food and Agriculture Organization of the United Nations.

\section{Copyrights}

Copyright for this article is retained by the author(s), with first publication rights granted to the journal.

This is an open-access article distributed under the terms and conditions of the Creative Commons Attribution license (http://creativecommons.org/licenses/by/4.0/). 